\title{
The Atlantic Healthcare Collaboration: Is it Time to Challenge the West-East Health Gradient in Canada?
}

\author{
Terrence Sullivan, $\mathrm{P} \mathrm{D}$ \\ President, Terrence Sullivan \& Associates \\ Professor and Senior Fellow, Institute for Health Policy, Management and Evaluation \\ University of Toronto \\ Toronto, ON \\ $\infty$
}

In THis EDITION of Healthcare Papers, we begin to understand the scale and pace of the turnaround that the Canadian Foundation for Healthcare Improvement (CFHI) has made in the last three years. During that time, building on a rich legacy of health services research and knowledge transfer, the organization has refocused away from the funding and production of health services research linking producers and decision-makers, which was a hallmark of the Canadian Health Services Research Foundation (CHSRF). The organization has evolved the capacity-building ambitions of its predecessor toward the challenge of directly advancing health services through collaborative improvement initiatives informed by filtered evidence. CFHI has pragmatically adopted elements from leading healthcare improvement collaborative organizations like the Institute for Healthcare Improvement and other improvement initiatives in the US, the UK, Sweden and elsewhere to advance healthcare improvement and performance in Canada in a pan-Canadian fashion.

This collection documents the ambitious undertaking of one of its larger improvement efforts to build not just sub-regional or province-wide initiatives, but rather the four-province region of Atlantic Canada, which was joined through a common charter with CFHI as a large laboratory for healthcare improvements. An appropriate laboratory it is indeed, since Atlantic Canada bears the disproportionate burden of illness and poor health outcomes in the West (better 
health status) to East (poorer health status) gradient that characterizes health status in our country. This important challenge faced by the Atlantic Healthcare Collaboration for Innovation and Improvement in Chronic Disease (AHC) is well laid out in the lead paper by Verma, Denis and colleagues (2016) and by Wedge and Currie (2016). The lead paper nicely characterizes the range of targeted improvement ambitions, and the variety of interventions associated with the $\mathrm{AHC}$ and the CFHI support to assist with these interventions.

The commentaries that follow are informed by the CFHI six levers framework for accelerating healthcare improvement to further our understanding of how to create and sustain patient- and family-centred approaches in chronic care (CFHI n.d.). These levers are revisited in the closing commentary, where the lead authors respond (Verma, Samis et al. 2016).

- How do we deliver population-based care? And how do we engage healthcare providers and front-line managers in delivering good chronic illness care (Wagner 2016)?

- How do we build organizational capacity as well as create supportive policies and incentives that foster an environment for improvement (Wedge and Currie 2016)?

- How do we engage patients and families in working with providers to design and deliver care that better meets their needs (Vallis 2016)?

- How can we encourage teams to rely on best evidence and carry out performance measurement for tracking their progress toward better care (Phillips et al. 2016)?

- What can we learn about quality improvement collaboratives and their utility as a "template" for leading to systemic or at-scale improvement (Delgado 2016)?
As noted by all the contributors in this volume, the evidence that underpins quality improvement collaboratives is modest (Schouten et al. 2008) but a good basis on which to build and target improvement efforts. There do appear to be a number of promising new developments emerging to assist in refining the focus and methods underpinning collaboratives, and a number of these are discussed in the collection. Defining the common effective elements of quality improvement collaboratives appears to be a challenging but important part of the initial planning, since these do seem to be predictive of what may produce effective improvements, as noted in the recent contribution from Nadeem and colleagues (2013). In the opening paper, Verma, Denis and colleagues nicely summarize the limits and the promising directions for quality collaboratives (2016). As they reflect on the AHC and its progress and challenges, they thoughtfully map the elements of the AHC against the elements enumerated in the paper by Nadeem and colleagues (2013). They also do a second ambitious mapping of activity elements against the Seattle Chronic Care Model and the CFHI Improvement Approach phases of progress. The lead paper highlights measured progress in several initiatives undertaken through the $\mathrm{AHC}$, with a number still underway.

In tackling the range of health service improvement challenges in Atlantic Canada, the AHC with CFHI support undertook a "coalition of the willing" involving regional health authorities and clinical leaders in a number of particular areas across the Atlantic region and in partnership with their provincial health system leaders as well. Their aims were multiple, although turning on the common but very large challenge of improving chronic disease management. Pedro Delgado (2016), from the Institute for Healthcare Improvement, notes in his focused commentary the utility 
of collaboratives as a template for leading to systemic improvement. He notes the importance of uniting and mobilizing people around a common improvement aim as the starting point. He also highlights the challenges of trading off breadth and focus in improvement collaboratives. The AHC, he points out, had a range of aims, which increases the effort required to make measureable change. A focus on the way aims are framed and measured is essential to success, as explored by Philips and colleagues in their contribution as well (Phillips et al. 2016).

The team had the wisdom to engage Edward Wagner as a colleague, to inform and advise on the AHC chronic disease improvement collaboration, and his perspectives are as wise as they are targeted (Wagner 2016). In his focus on how to deliver population-based care and engage providers and front-line managers, he points to the possibilities inherent in the engagement of primary care physicians as key agents of improvement. He also points to the importance and the promise of patient and family engagement in the design of initiatives, including self-management. The focus on effective engagement of primary care is common to almost all successful population health improvement efforts. There is some clear evidence that well-designed, primary care improvement initiatives can improve diabetes management, particularly if $\mathrm{HbA} 1 \mathrm{C}$ is poorly controlled to begin with (Tricco et al. 2012).

It is also apparently possible to make sustained improvement through primary care if the effort is sustained, as recently illustrated by the Australian Primary Care Collaboratives program in the case of diabetes care (Knight et al. 2012). This Australian program delivered the improvement in no less than seven waves over five years, serving a large population of patients with diabetes, who showed $50 \%$ improvements in $\mathrm{HbA} 1 \mathrm{C}$ along with comparable improvement in lipid levels and blood pressure measures. An interesting and skeptical editorial by O'Connor (2012), accompanying the Australian paper, points out the importance of enriching electronic prompts to ensure that future improvement collaboratives have a more nuanced, richer base of evidence-informed informatics support to advance improvement and patient-centred care in the future.

Thoughtful inputs from Vallis (2016) highlight the promise and the importance of engaging patients and families through working with providers to design and deliver care that best meets patient needs. In his view, the provider's role lies, in large measure, in helping the patient discover their own reasons for change as the key to improved self-management not to impost a provider's opinion. This is an under-developed focus in better disease state management. Vallis (2016) argues for a simple behavioural imperative to promote self-management: assess understanding and agreement as a stepping stone to the design of self-management tools (Wilson and Holt 2003). In this way, tools can be refined with patients through further adaptation to their understanding and agreement, and intervention strategies can be revised to be consistent with their understanding and agreement.

In their thorough piece on how to encourage teams to rely on best evidence and to measure performance to track progress toward better care, Phillips and colleagues (2016) draw out several lessons for the design and measurement of the $\mathrm{AHC}$ that generate a broader set of reflections for the work program of CFHI itself. They discuss a number of the areas that were strong design underpinnings to the collaborative - the challenges of ongoing measurement, planning and reporting; building team measurement capacity; coaching and support for evaluation and measurement; and additional social networking and costing analyses. Their lesson extends to 
some critical elements as well - perhaps the duration of the AHC intervention was a little too short to produce measured improvements in a number of areas and could have benefited from further extension of the intervention support. In addition, the issue of how broad or how targeted the improvement intervention was turns out to be a point of active reflection, as is common in improvement collaboratives. Certainly it is easier to narrowly focus on disease-specific interventions and outcome measures where there are emerging "packages" of interventions and where the benefits of electronic supports might offer additional momentum to standardize optimal care.

Phillips and colleagues (2016) reflect thoughtfully on the importance of the AHC for the entire portfolio of current improvement initiatives, a portfolio that is currently evolving, with some targeted areas of focus. The entire organization is working with the national challenge of innovation and improvement, an area of focus where CFHI received an enthusiastic shout-out in the report of the federal Advisory Panel on Healthcare Innovation, recently released in the summer of 2015 (Advisory Panel on Healthcare Innovation 2015).

It is interesting to look at the AHC as an innovative collaboration of executive and clinical leaders along with provincial policy makers within Atlantic Canada. In many ways, their situation is one where the AHC highlighted the capacity to generate some modest care improvements, which may take on a longer-term momentum.

Wedge and Currie in their commentary take on the topical question of how to build organization capacity as well as create supportive policies for improvement (2016). They note that at least some provincial policies related to team-based professional collaboration appear to be working in favour of better chronic disease management and care.
They also point out, as leading denizens of our smallest province, that Prince Edward Island is already highly integrated with neighbouring Nova Scotia and New Brunswick for complex surgery, among other subspecialty medical services. A clear policy for regionalization of complex surgery in Atlantic Canada may be an important further step to consider in the future (Finley et al. 2015).

Indeed, an overall strategy for Atlantic Canada might be an interesting next phase to support greater focus on prevention and specific disease-state management. Certainly many of the challenges to health status in the Atlantic region have their roots in the social determinants of health reflected in the conditions in which people live and work, with poorer health status being a reflection of poorer overall economic conditions and circumstance. A full push toward a reversal of the West-East gradient would need to take a bigger look at the social dimensions of health status in Atlantic Canada and the full mobilization of the public and primary healthcare leadership in the region. It would perhaps also take a more active look at the policy levers at the disposal of host governments in the region. Is a kind of North Karelia (Finland) scale of improvement effort (Puska 2010) not possible in Atlantic Canada?

Certainly, health spending in Atlantic Canada is above the Canadian average, with BC, Ontario and Quebec (three quarters of Canada) spending less per capita. While there may be a cost case for the health status burden in Atlantic Canada, there may also be a case for extracting greater value from all players in the region, including physician and health professional bargaining. The capacity to appeal to the civic engagement of practice leaders in Atlantic Canada has been stimulated, and perhaps there is a way of capitalizing on the idea of delivering better value, as is being argued with the emergence of 
value-based arrangements in the US (Young 2013).

Canada has a limited set of improvement capacities beyond provincial quality councils, CFHI and some specialty areas of medicine, including cardiac, cancer, stroke, pediatrics and of course public health. The AHC has done an elegant job of highlighting the possibilities and the promise of launching innovative improvement initiatives to deal with large disparities in the health status of specific populations in Canada. Our resources for capacity development and improvement are thinly spread, and the Advisory Panel on Healthcare Innovation (2015) has thoughtfully recommended that these resources be expanded dramatically to move us systematically to a higher level of health system performance.

As Verma, Samis and colleagues (2016) note in their closing response, the AHC remains a large experiment that has provided an important regional input to the evolution of a learning healthcare system in Canada, supported by innovation and improvement processes. Can we take it a step further, Atlantic Canada?

\section{References}

Advisory Panel on Healthcare Innovation. 2015. Report of the Advisory Panel on Healthcare Innovation. Accessed November 21, 2015. <http://www.healthycanadians.gc.ca/publications/health-system-systemesante/report-healthcare-innovation-rapport-soins/ index-eng.php>.

Canadian Foundation for Healthcare Improvement (CFHI). n.d. "CFHI's Six Levers to Help Organizations Accelerate Healthcare Improvement." Accessed November 21, 2015. <http://www.chi-fcass. ca/PublicationsAndResources/ResourcesAndTools/ six-levers>.

Delgado, P. 2016. "Meeting the Challenge of Chronic Conditions in a Sustainable Manner: Building on the AHC Learning." Healthcare Papers 15(Special Issue, January): 90-5. doi:10.12927/hcpap.2016.24504

Finley, C., L. Schneider and S. Shakeel. 2015. Approaches to High-Risk, Resource Intensive Cancer
Surgical Care in Canada. Accessed November 21, 2015. <http://www.cancerview.ca/idc/groups/public/documents/document/high_risk_resource_full_report_ en.pdf>.

Knight, A.W., D. Ford, R. Audehm, S. Colagiuri and J. Best. 2012. "The Australian Primary Care Collaboratives Program: Improving Diabetes Care." BMJ Quality E Safety 21(11): 956-63. doi:10.1136/ bmjqs-2011-000460

Nadeem, E., S.S. Olin, L.C. Hill, K.E. Hoagwood and S.M. Horwitz. 2013. "Understanding the Components of Quality Improvement Collaboratives: A Systematic Literature Review." Milbank Quarterly 91(2): 354-94. doi:10.1111/milq.12016

O'Connor, P. 2012. "Quality Improvement Collaboratives in the Age of Health Informatics New Wine in New Wineskins." BMJ Quality E Safety 21(11): 891-93. doi:10.1136/bmjqs-2012-001265

Phillips, K., C. Amar and K. Elicksen. 2016. "Evaluating a Chronic Disease Management Improvement Collaboration: Lessons in Design and Implementation Fundamentals." Healthcare Papers 15(Special Issue, January): 80-9. doi:10.12927/ hcpap.2016.24505

Puska, P. 2010. "From Framingham to North Karelia: From Descriptive Epidemiology to Public Health Action." Progress in Cardiovascular Diseases 53(1): 15-20. doi:10.1016/j.pcad.2010.01.003

Schouten, L.M., M.E. Hulscher, J.J. van Everdingen, R. Huijsman and R.P. Grol. 2008. "Evidence for the Impact of Quality Improvement Collaboratives: Systematic Review." British Medical Journal 336: 1491-94. doi:10.1136/bmj.39570.749884.BE

Tricco, A.C., N.M. Ivers, J.M. Grimshaw, D. Moher, L. Turner, J. Galipeau et al. 2012. "Effectiveness of Quality Improvement Strategies on the Management of Diabetes: Systematic Review and Meta-Analysis." The Lancet 379: 2252-61. doi.org/10.1016/S01406736(12)60480-2

Vallis, M. 2016. "A Collaborative Approach to a Chronic Care Problem: An Academic Mentor's Point of View." Healthcare Papers 15(Special Issue, January): 74-9. doi:10.12927/hcpap.2016.24503

Verma, J.Y., J.-L. Denis, S. Samis, F. Champagne and M. O'Neil. 2016. "A Collaborative Approach to a Chronic Care Problem." Healthcare Papers 15(Special Issue, January): 19-60. doi:10.12927/ hcpap.2016.24503

Verma, J.Y., S. Samis, J-L. Denis, M. O’Neil and F. Champagne. 2016. "A Last Word on Collaborating for Lasting Change." Healthcare Papers 15(Special Issue, January): 97-109. doi:10.12927/hcpap.2016.24507 
Introduction

Wagner, E.H. 2016. "A First Step on the Journey to High-Quality Chronic Illness Care.” Healthcare Papers 15(Special Issue, January): 62-66. doi:10.12927/

hcpap.2016.24506

Wedge, R. and Hon. D.W. Currie. 2016. "SystemLevel Reform in Healthcare Delivery for Patients and Populations Living With Chronic Disease."

Healthcare Papers 15(Special Issue, January): 67-73. doi:10.12927/hcpap.2016.24508

Wilson, T. and T. Holt. 2003. "Complexity and Clinical Care.” British Medical Journal 323: 685-88.

Young, G.J. 2013. "Redefining Payer-Provider Relationships in an Era of Pay for Performance: A Social Capital Perspective." Quality Management in Health Care 22(3): 187-98. doi:10.1097/

QMH.0b013e31829a6af3 


\title{
La Collaboration des organismes de santé de l'Atlantique : le moment est-il venu de remettre en question le gradient de la santé Ouest-Est au Canada?
}

\author{
Terrence Sullivan, $\mathrm{PHD}$ \\ Président, Terrence Sullivan \& Associates \\ Professeur et attaché de recherche, Institute of Health Policy, Management and Evaluation \\ Université de Toronto \\ Toronto, $\mathrm{ON}$ \\ $\infty$
}

Dans ce numéro de Healthcare Papers, nous commençons à comprendre l'ampleur du changement de cap effectué par la Fondation canadienne pour l'amélioration des services de santé (FCASS) au cours des trois dernières années, et la rapidité avec laquelle il a été réalisé. Au cours de cette période, et en s'appuyant sur une mine de recherche en matière de services de santé et de transfert des connaissances, l'organisation s'est redéfinie, en abandonnant une des caractéristiques principales de la Fondation canadienne de la recherche sur les services de santé (FCRSS), à savoir le financement et la réalisation d'activités de recherche sur les services de santé qui rassemblaient jusqu'alors les chercheurs et les décideurs. L'organisation a voulu aller plus loin que celle qui l'avait précédée, en ne se limitant pas au renforcement des capacités, mais en faisant progresser concrètement les services de santé grâce à des projets collaboratifs d'amélioration éclairés par des données probantes. La FCASS a adopté de manière pragmatique certains éléments d'organismes de prestation de soins de pointe engagés dans des projets de collaboration, tels que le Institute 
for Healthcare Improvement et d'autres établissements aux États-Unis, au RoyaumeUni, en Suède et ailleurs dans le monde, pour promouvoir l'amélioration et le rendement des services de santé partout au Canada.

Cette collection documente une de ses entreprises les plus ambitieuses, une initiative d'amélioration visant à établir un projet de collaboration au niveau des quatre provinces du Canada atlantique, dépassant donc largement le cadre régional ou provincial, régi par une charte commune avec la FCASS agissant à titre de grand laboratoire pour l'amélioration des services de santé. C'est en effet un laboratoire des plus appropriés, puisque le Canada atlantique supporte de manière disproportionnée le fardeau de la maladie et de la mauvaise santé au pays, dans le gradient Ouest (meilleur état de santé) Est (moins bon état de santé) qui caractérise la santé au Canada. Cet important défi que voulait relever la Collaboration des organismes de santé de l'Atlantique (COSA) en matière d'innovation et d'amélioration dans le traitement des maladies chroniques est bien illustré dans le document d'orientation de Verma, Denis et leurs collègues (2016) et de Wedge et Currie (2016). Le document d'orientation décrit de manière équilibrée la gamme des projets d'amélioration ciblés et la variété des interventions proposées, avec le soutien de la Collaboration des organismes de santé de l'Atlantique et de la FCASS.

Les commentaires qui suivent s'appuient sur les six leviers d'action pour accélérer l'amélioration des services de santé, élaborés par la FCASS afin de nous permettre de mieux comprendre comment créer et soutenir des approches centrées sur les patients et les familles dans le traitement des maladies chroniques (FCASS). Nous reviendrons sur ces leviers d'action dans la conclusion, avec les réponses fournies par les auteurs principaux (Verma, Samis et al. 2016).
- Comment pouvons-nous offrir des soins centrés sur les patients? Et comment pouvons-nous mobiliser les prestataires de soins et les gestionnaires de première ligne pour qu'ils offrent des soins de qualité dans le traitement des maladies chroniques (Wagner 2016)?

- Comment pouvons-nous renforcer les capacités organisationnelles et créer des politiques et des mesures incitatives de soutien qui favorisent un environnement propice à l'amélioration (Wedge et Currie 2016)?

- Comment pouvons-nous inciter les patients et leurs familles à travailler avec les prestataires pour concevoir et fournir des soins qui répondent mieux à leurs besoins (Vallis 2016)?

- Comment pouvons-nous encourager les équipes à s'appuyer sur les meilleures données probantes et à effectuer des mesures du rendement afin de suivre les progrès accomplis dans la prestation de soins de meilleure qualité (Phillips et al. 2016) ?

- Que pouvons-nous apprendre des projets collaboratifs d'amélioration de la qualité ? Peuvent-ils servir de tremplins vers des améliorations systémiques ou à grande échelle (Delgado 2016)?

Comme l'ont indiqué tous les collaborateurs de ce document, les éléments de preuve qui sous-tendent les projets collaboratifs d'amélioration de la qualité sont modestes (Schouten et al. 2008), mais ils constituent néanmoins un bon point de départ pour élaborer et cibler des initiatives d'amélioration. Un certain nombre de nouveautés prometteuses pourraient permettre d'affiner les objectifs et les méthodes de ces projets collaboratifs, et nous en abordons plusieurs dans la collection. La définition des éléments efficaces communs aux projets collaboratifs 
d'amélioration de la qualité semble représenter une tâche difficile, mais néanmoins importante, de la planification initiale, puisque ces éléments semblent pouvoir prévoir ce qui pourrait entraîner des améliorations efficaces, comme l'ont récemment indiqué Nadeem et ses collègues (2013). Dans le document d'introduction, Verma, Denis et leurs collègues résument bien les limites et les orientations prometteuses des projets collaboratifs d'amélioration de la qualité (2016). En analysant la Collaboration des organismes de santé de l'Atlantique, les progrès accomplis et les défis à relever, ils comparent les éléments de la Collaboration des organismes de santé de l'Atlantique à ceux qui sont énumérés dans le document de Nadeem et de ses collègues (2013). Ils dressent également une deuxième comparaison d'envergure avec le Modèle de soins des maladies chroniques de Seattle et les phases de l'approche d'amélioration de la FCASS. Le document d'orientation souligne les progrès mesurés de plusieurs initiatives réalisées grâce à la Collaboration des organismes de santé de l'Atlantique, certains projets étant toujours en cours.

Pour faire face aux défis relatifs à l'amélioration des services de santé dans la région atlantique, la Collaboration des organismes de santé de l'Atlantique, avec le soutien de la FCASS, a mis sur pied, en partenariat avec les ministères de la Santé de toutes les provinces concernées, une « coalition des parties disposées à agir ", regroupant des autorités sanitaires régionales et des dirigeants cliniques, dans un certain nombre de domaines particuliers, de toute la région atlantique. Leurs objectifs multiples tournaient tous autour d'un grand défi commun : l'amélioration de la gestion des maladies chroniques. Dans ses commentaires ciblés, Pedro Delgado (2016), de l'Institute for Healthcare Improvement, note l'utilité des projets collaboratifs en tant que tremplins vers des améliorations systé- miques. Il souligne qu'il est important d'unir et de mobiliser les gens autour d'un objectif commun d'amélioration dès le départ. Il expose également les défis que représentent les compromis en matière de portée et de ciblage auxquels il faut arriver dans les projets collaboratifs d'amélioration. Il explique que la Collaboration des organismes de santé de l'Atlantique avait toute une série d'objectifs, ce qui exigeait des efforts supplémentaires pour que des changements mesurables voient le jour. La façon dont les objectifs sont définis et mesurés est essentielle à la réussite, comme l'ont aussi indiqué Philips et ses collègues dans leurs commentaires (Phillips et al. 2016).

L'équipe a eu la sagesse d'engager Edward Wagner en tant que collaborateur, pour qu'il offre des renseignements et des conseils sur le projet collaboratif d'amélioration du traitement des maladies chroniques de la Collaboration des organismes de santé de l'Atlantique. Ses perspectives sont aussi sages que ciblées (Wagner 2016). Sur la façon de fournir des soins centrés sur le patient et de mobiliser les prestataires de soins et les gestionnaires de première ligne, il souligne les possibilités inhérentes à l'engagement des médecins de soins primaires, en tant que catalyseurs de l'amélioration. Il souligne également l'importance et la promesse de la participation des patients et de leurs familles à la conception des initiatives, y compris l'autogestion. La participation effective des médecins de soins primaires est une condition que l'on retrouve dans presque toutes les initiatives réussies d'amélioration de la qualité des soins. Certains éléments prouvent de manière indubitable que des initiatives bien conçues d'amélioration de la qualité des soins primaires peuvent améliorer la gestion du diabète, en particulier si le taux d'HbA1c est mal contrôlé au départ (Tricco et al. 2012).

Il est aussi apparemment possible de réaliser des améliorations pérennes dans le 
domaine des soins primaires avec un effort soutenu, comme l'a récemment illustré le Programme australien de projets collaboratifs dans le domaine des soins primaires, plus particulièrement pour les soins du diabète (Knight et al. 2012). Dans ce programme australien, l'amélioration de la qualité des soins s'est faite en sept vagues successives sur une période de cinq ans. Les nombreux patients atteints de diabète ayant bénéficié de ce programme ont vu leur taux d'HbA1c s'améliorer de $50 \%$, avec une amélioration comparable au niveau des taux de lipides et de la tension artérielle. Un éditorial intéressant et critique de O'Connor (2012) accompagnait le rapport australien et soulignait qu'il est important d'enrichir les données électroniques pour faire en sorte que les projets collaboratifs futurs bénéficient d'une banque informatique de données probantes plus riches et plus nuancées, afin de faciliter l'amélioration et les soins centrés sur le patient.

Les commentaires pertinents de Vallis (2016) mettent en évidence la promesse et l'importance de la collaboration entre les patients, leurs familles et les prestataires de soins, pour concevoir et fournir des soins qui répondent le mieux aux besoins des patients. À son avis, le rôle du prestataire n'est pas d'imposer son opinion, mais dans une large mesure d'aider le patient à découvrir les raisons qui le poussent au changement : c'est là que réside la clé de l'amélioration de l'autogestion. C'est un aspect auquel on n'accorde pas suffisamment d'attention lorsqu'on parle d'amélioration de la gestion des pathologies. Vallis (2016) plaide pour un impératif de comportement simple afin de promouvoir l'autogestion : évaluer la compréhension et l'accord des patients pour qu'ils servent de tremplin à la conception d'outils d'autogestion (Wilson et Holt 2003). De cette façon, des outils peuvent être affinés avec les patients, grâce à l'adaptation de leur compréhension et de leur accord, et les stratégies d'intervention peuvent être révisées pour qu'elles demeurent cohérentes avec leur compréhension et leur accord.

En expliquant comment il est possible d'encourager les équipes à s'appuyer sur les meilleures données probantes et à effectuer des mesures du rendement, afin de suivre les progrès accomplis dans la prestation de soins de meilleure qualité, Phillips et ses collègues (2016) tirent plusieurs leçons relatives à la conception et à la mesure de la Collaboration des organismes de santé de l'Atlantique ; des leçons qui génèrent un ensemble plus large de réflexions pour le programme de travail de la FCASS elle-même. Ils discutent de certains des piliers de la conception du projet collaboratif - les défis de la mesure continue, la planification et les rapports ; le renforcement de la capacité de mesure de l'équipe; l'encadrement et le soutien pour l'évaluation et la mesure ; et les analyses de réseautage social et de coûts supplémentaires. Leur analyse s'attarde aussi sur certains éléments critiques la durée de l'intervention de la Collaboration des organismes de santé de l'Atlantique était peut-être un peu trop courte pour produire des améliorations mesurées dans un certain nombre de domaines : une prolongation de l'intervention aurait pu s'avérer bénéfique. En outre, la portée et le ciblage de l'intervention d'amélioration se révèlent être des points de réflexion intense, comme cela est souvent le cas dans les projets collaboratifs d'amélioration. Il est certainement plus facile de se concentrer sur des interventions spécifiques à certaines pathologies et sur des mesures de résultats, là où des interventions groupées et des supports électroniques sont en mesure d'offrir un élan supplémentaire à la normalisation de soins optimaux.

Phillips et ses collègues (2016) réfléchissent sérieusement à l'importance de la Collaboration des organismes de santé de 
l'Atlantique pour l'ensemble du portefeuille des initiatives d'amélioration actuelles, un portefeuille en pleine évolution, avec quelques domaines d'intérêt ciblés. L'ensemble de l'organisation opère dans le cadre du défi national en matière d'innovation et d'amélioration, un secteur où la FCASS a reçu des éloges enthousiastes de la part du Groupe consultatif fédéral sur l'innovation des soins de santé, dans son rapport publié au cours de l'été 2015 (Libre cours à l'innovation: Soins de santé excellents pour le Canada, 2015).

Il est intéressant de considérer la Collaboration des organismes de santé de l'Atlantique comme un projet collaboratif novateur de dirigeants exécutifs et cliniques et de décideurs provinciaux du Canada atlantique. À bien des égards, on peut dire que la Collaboration des organismes de santé de l'Atlantique a montré qu'elle était capable d'apporter des améliorations de soins modestes, qui pourraient prendre un nouvel élan à long terme.

Dans leurs commentaires, Wedge et Currie s'attaquent à une question d'actualité : comment renforcer les capacités organisationnelles et créer des politiques de soutien pour favoriser l'amélioration (2016) ? Ils notent que certaines politiques provinciales relatives à la collaboration professionnelle semblent œuvrer en faveur d'une meilleure gestion et d'un meilleur traitement des maladies chroniques. Ils soulignent également, en tant que citoyens très en vue d'une petite province, que l'Île-du-Prince-Édouard est déjà fortement intégrée avec les provinces voisines de la Nouvelle-Écosse et du Nouveau-Brunswick pour toutes les chirurgies complexes et d'autres services médicaux de sous-spécialités. Une politique claire en matière de régionalisation pour les chirurgies complexes dans les provinces atlantiques pourrait être une autre étape importante à considérer à l'avenir (Finley et al. 2015).
En effet, une stratégie globale pour le Canada atlantique pourrait être une prochaine phase intéressante, qui permettrait de se concentrer encore plus sur la prévention et la gestion de certaines maladies spécifiques. Il est indéniable que plusieurs des défis en matière de santé dans la région de l'Atlantique trouvent leur explication dans les déterminants sociaux de la santé, reflétés par les conditions dans lesquelles les gens vivent et travaillent ; un état de santé précaire étant le reflet de conditions économiques et de circonstances générales plus défavorables. Un renversement complet du gradient Ouest-Est nécessiterait qu'on examine de plus près les dimensions sociales de l'état de santé du Canada atlantique et qu'on mobilise le public et les dirigeants des services de santé primaires dans la région. Il faudrait également peut-être étudier de manière plus proactive les leviers politiques dont disposent les gouvernements hôtes dans la région. Pourquoi un effort d'amélioration similaire à ce qui a été mis en œuvre en Carélie du Nord (Finlande) (Puska 2010) ne serait-il pas possible dans les provinces atlantiques?

Il est incontestable que les dépenses de santé au Canada atlantique sont supérieures à la moyenne canadienne; la ColombieBritannique, l'Ontario et le Québec (les trois quarts du Canada) dépensant moins par habitant. Bien que les coûts puissent être montrés du doigt pour expliquer en partie la précarité de l'état de santé dans les provinces atlantiques, on pourrait également citer le besoin d'extraire un maximum de valeur de tous les acteurs de la région, notamment des médecins et des négociateurs professionnels du secteur de la santé. La possibilité de faire appel à l'engagement civique des leaders du monde médical au Canada atlantique a été mise en avant, et il est peut-être possible de miser sur l'idée de fournir une valeur supérieure, comme le fait valoir l'émergence d'arrangements fondés sur la valeur aux États-Unis (Young 2013). 
Le Canada dispose d'un ensemble limité de capacités d'amélioration, au delà des conseils provinciaux de la qualité, de la FCASS et de certains domaines médicaux spécialisés, y compris la santé cardiaque, le cancer, les accidents vasculaires cérébraux, la pédiatrie et bien sûr la santé publique. La Collaboration des organismes de santé de l'Atlantique a bien réussi à mettre en évidence les possibilités et les promesses de certaines initiatives d'amélioration innovantes pour réduire les grandes disparités existant dans l'état de santé de populations spécifiques au Canada. Nos ressources pour le développement des capacités et l'amélioration sont dispersées, et le Groupe consultatif sur l'innovation des soins de santé (2015) a judicieusement recommandé que ces ressources soient considérablement augmentées pour nous faire passer de manière systématique à un niveau supérieur de rendement dans le système de santé.

Comme Verma, Samis et leurs collègues (2016) le font remarquer dans leur conclusion, la Collaboration des organismes de santé de l'Atlantique reste une grande expérience qui a permis à la région de contribuer à l'évolution d'un système de soins de santé prêt à se remettre en cause au Canada, avec le soutien de processus d'innovation et d'amélioration appropriés. Canada atlantique : pouvons-nous pousser un peu plus loin?

\section{Références}

Les références peuvent être trouvés à l'adresse: http://www.longwoods.com/content/24525 